\title{
Emergence of cannabis as the second most commonly used psychoactive substance among students
}

Open acess

${ }^{1}$ Dentistry student of Faculdade Meridional/IMED, RS, Brazil

${ }^{2}$ Department of Dentistry, Faculdade Meridional, Brazil

Corresponding author:

lilianrigo@imed.edu.br/lilianrigo@via-rs.net

Manuscript received: 25 January 2017 Manuscript accepted: 02 August 2017 Version of record online: 06 September 2017

\author{
Thaíse Vincenzi ${ }^{1}$, Débora Nunes Mario², Graziela Oro Cericato², \\ Michele Natara Portilio', Lilian Rigo²
}

\begin{abstract}
Introduction: People use psychoactive substances (PAS) historically; however, from the 1960s on, this use has increased considerably, becoming known for compromising health and causing the death of millions of people every year.

Objective: This study aimed to verify the prevalence of psychoactive substances consumed by dentistry students, as well as to analyze the influence of sociodemographic variables and identify the level of life satisfaction among Dentistry students.
\end{abstract}

Methods: It is a cross-sectional observational study including 159 students of an educational institution in a city of southern Brazil enrolled in the eight course periods. They were anonymously asked to a self-administered questionnaire regarding sociodemographic variables and use of psychoactive substances (PAS), questions were adapted by the validated instrument called Alcohol, Smoking and Substance Involvement Screening Test (ASSIST), and the assessment of level of life satisfaction by the Satisfaction With Life Scale (SWLS).

Results: The use of PAS at some point in life had prevalence of $90.6 \%$. Alcohol was the most used PAS by students, followed by cannabis. The use of drugs for depression showed association with alcohol and cannabis consumption, cannabis was predominately consumed by male. The majority of students reported dissatisfaction with life.

Conclusion: The prevalence of PAS use is high among the Dentistry students interviewed. The PAS most consumed by students was alcohol, followed by cannabis, psychoactive drugs, and tobacco.

Keywords: street drugs, drug users, narcotics, students, dental, cannabis 


\section{INTRODUCTION}

People use psychoactive substances (PAS) historically ; however, from the 1960s on, this use has increased considerably, becoming known for compromising health and causing the death of millions of people every year ${ }^{1,2}$. Psychoactive substances include illicit and licit drugs, and psychoactive drugs. Alcohol and tobacco are licit drugs, while cannabis, cocaine, heroin, lysergic acid diethylamide (LSD), crack, and ecstasy are illicit drugs in many countries, just like in Brazil, where this study was done. The abuse of stimulants such as amphetamines, either prescribed or not, has also been reported ${ }^{3,4}$.

Physical changes among PAS users have been also reported. In oral health, for example, there are periodontal problems, bone losses, change in salivary flow, frequent caries, xerostomia, pain, and bruxism ${ }^{5}$.

The early use of PAS affects all social levels and is increasingly among young students, causing a global concern $^{6}$. Age, gender, level of education of users and

\section{METHODS}

\section{Sample qualification and study location}

This is an observational research with quantitative approach and cross-sectional design. The sample included all students enrolled in the eight terms of the Dentistry course of Faculdade Meridional (IMED), Passo Fundo, Rio Grande do Sul, Brazil. The total population of students enrolled was 190 at that given time, from data collected in the department of academic records of the institution. A $95 \%$ confidence interval was used to calculate the sample and a further $16 \%$ was added, which was finalized in 159 dentistry students. The data collection period was August 2015.

The study verified the guidelines of Resolution $n$. 466/12 of the National Health Council, and was approved by the Research Ethics Committee of IMED, under number 752.939. Participants were explained about the research objectives, received information on the method, and consented to participate in the study, which was made official by signing the Informed Consent Form (ICF) for data collection.

\section{Procedures and instruments for data collection}

Data were collected through the application of an anonymous self-administered questionnaire including questions regarding PAS use, complemented by sociodemographic variables and the Satisfaction With Life Scale. The questions about PAS use were supported by the validated instrument known as Alcohol, Smoking and Substance Involvement Screening Test (ASSIST) ${ }^{9}$. This questionnaire used in primary care aims to perform a screening of the abuse of alcohol, tobacco, and illicit drugs, but it is not a self-administered questionnaire. Thus, we used an adaptation of this instrument, proposed by Rocha et al. ${ }^{10}$, who developed the self-administered questionnaire allowing identifying the prevalence and pattern of alcohol and drug use among health professionals. In addition, the Satisfaction With Life Scale (SWLS), created in the early 1980 s, is a self-administered instrument of five items which parents, and having family members or friends who are addicted to drugs, are factors known for influencing PAS use $^{6}$. The use of PAS among university students of the health field deserves special attention, mostly because those future professionals are responsible for identifying and referring patients with problems related to drug use, and for being a role model behavior for their patients? This research has scientific and social relevance, which aims to contribute with evidence for further research on the profile of the future student/professional and the use of psychoactive substances.

Despite the increasing number of drug users, this class of special patients is still little explored, this could affect the way how health professionals are handling those patients ${ }^{8}$.

The present study aimed to verify the prevalence of psychoactive substances (PAS) among Dentistry students, analyze the influence of sociodemographic variables and identify the level of life satisfaction of those students.

intends to assess the cognitive component of the subjective well-being, that is, life satisfaction (very dissatisfied, dissatisfied, slightly dissatisfied, neither satisfied nor dissatisfied, slightly satisfied, satisfied, and very satisfied). Through a global assessment rather than specific aspects of life, respondents themselves may choose what is essential for their satisfaction with $\operatorname{life}^{11}$. The questionnaire was applied as follows: the objective of the research was explained and all students present in the classroom were invited to participate, with anonymity guarantee.

Variables were grouped through criteria, in order to categorize study variables and frequency distribution: 1) sociodemographic data - course term (4 years), age group, gender, marital status, home residents, work outside the home; 2) data on life satisfaction - very dissatisfied, dissatisfied, slightly dissatisfied, neither satisfied nor dissatisfied, slightly satisfied, satisfied, and very satisfied. 3) data on psychoactive substance use - alcoholic beverages, anxiolytics, tranquilizers, sedatives, weight loss drugs, tobacco derivatives, cannabis, cocaine, crack, ecstasy; use for - relaxing/stress relief, rejoice/celebrate, control depression/fear, control need to eat, public speaking, studying, pain control, sleeping, others; frequency of drug use over the last days - none, once a week, more than once a week, almost every day, daily; classroom absence due to alcohol and drug use; is/was diagnosed with depression; and use of drugs for depression (self-reported chronic diseases - depression).

\section{Data analysis}

Data were electronically processed with the Statistical Package for Social Science software (SPSS), version 18.0. Thus, prevalence and frequencies of all variables were analyzed by descriptive statistics. Inferential statistics were used to assess the association between the dependent variables chosen by the highest prevalence of substances used by students: 1. Alcohol consumption- (yes and no, and 2). Cannabis use- (yes 
and no), and sociodemographic independent variables: course terms (terms I to IV and terms V to VIII), gender (male and female), age group (16-25 years and 26 years or older), marital status (single and married/stable union),

\section{RESULTS}

Table 1 describes data on the occurrence of independent variables (distribution of sociodemographic and satisfaction with life (SWLS) variables of Dentistry students of IMED. The prevailing age group was 19 to 25 years $(87.4 \%)$, and the majority was of the female gender (77.4\%) (Table 1). home residents (alone and friends/family members), work outside home (no and yes), use of drugs for depression (no and yes), life satisfaction (1- very dissatisfied/dissatisfied and 2 to 7 - other categories- others).

Table 1:Distribution of sociodemographic and satisfaction with life (SWLS) variables of Dentistry students of Faculdade Meridional (IMED), 2015.

\begin{tabular}{|c|c|c|}
\hline Sociodemographic variables & n (159) & $\%(100)$ \\
\hline \multicolumn{3}{|l|}{ Term (year) } \\
\hline Year I & 51 & 32.1 \\
\hline Year II & 37 & 23.3 \\
\hline Year III & 30 & 18.9 \\
\hline Year IV & 41 & 25.8 \\
\hline \multicolumn{3}{|l|}{ Age group } \\
\hline $16-18$ years & 5 & 3.1 \\
\hline $19-25$ years & 139 & 87.4 \\
\hline 26 years or older & 15 & 9.5 \\
\hline \multicolumn{3}{|l|}{ Gender } \\
\hline Male & 36 & 22.6 \\
\hline Female & 123 & 77.4 \\
\hline \multicolumn{3}{|l|}{ Marital Status } \\
\hline Single & 150 & 94.3 \\
\hline Married/Stable Union & 9 & 5.7 \\
\hline \multicolumn{3}{|l|}{ Home residents } \\
\hline Alone & 38 & 23.9 \\
\hline Family members & 85 & 53.5 \\
\hline Friends & 36 & 22.6 \\
\hline \multicolumn{3}{|l|}{ Work outside the home } \\
\hline No & 152 & 95.6 \\
\hline Yes & 7 & 4.4 \\
\hline \multicolumn{3}{|l|}{ Satisfaction with life variables } \\
\hline Very dissatisfied & 63 & 39.6 \\
\hline Dissatisfied & 72 & 45.3 \\
\hline Slightly dissatisfied & 20 & 12.6 \\
\hline Neither satisfied nor dissatisfied & 3 & 1.9 \\
\hline Slightly satisfied and satisfied & 1 & 0.6 \\
\hline Very satisfied & 0 & 0 \\
\hline
\end{tabular}

For the bivariate analysis, two models were created to verify associations and were used to test the hypothesis of equality and equivalence among proportions, at $95 \%$ confidence interval and 5\% significance level, between independent variables and two of the PAS mostly used by students. Hence, in one of the models, the dependent variable included use of alcoholic substance, and in the other model, the variable was use of cannabis.

The results of inferential analysis by Person's chisquare test and Fisher's exact test showed the variable of
Table 2 describes data on the occurrence of PAS use variables. It was verified that $90.6 \%$ of students used it at some point in life. The substance most used by students was alcohol ( $90.6 \%)$, followed by cannabis $(31.4 \%)$. In addition, when questioned about depression diagnosis, $87.4 \%$ affirmed having never been diagnosed with it or being under treatment with antidepressant drugs (Table 2). 
Table 2: Distribution of variables related to the use of psychoactive substances by Dentistry students of Faculdade Meridional (IMED), 2015.

\begin{tabular}{|c|c|c|}
\hline Use of psychoactive substance variables & n (159) & $\%(100)$ \\
\hline \multicolumn{3}{|l|}{ Alcoholic beverage } \\
\hline No & 15 & 9.4 \\
\hline Yes & 144 & 90.6 \\
\hline \multicolumn{3}{|c|}{ Anxiolytics, tranquilizers, sedatives, weight loss drugs } \\
\hline No & 116 & 73.0 \\
\hline Yes & 43 & 27.0 \\
\hline \multicolumn{3}{|l|}{ Tobacco derivatives } \\
\hline No & 125 & 78.6 \\
\hline Yes & 34 & 21.4 \\
\hline \multicolumn{3}{|l|}{ Cannabis } \\
\hline No & 109 & 68.6 \\
\hline Yes & 50 & 31.4 \\
\hline \multicolumn{3}{|l|}{ Cocaine } \\
\hline No & 156 & 98.1 \\
\hline Yes & 3 & 1.9 \\
\hline \multicolumn{3}{|l|}{ Crack } \\
\hline No & 159 & 100 \\
\hline \multicolumn{3}{|l|}{ LSD, ecstasy } \\
\hline No & 141 & 88.7 \\
\hline Yes & 18 & 11.3 \\
\hline \multicolumn{3}{|l|}{ Relaxation/stress relief } \\
\hline No & 63 & 39.6 \\
\hline Yes & 96 & 60.4 \\
\hline \multicolumn{3}{|l|}{ Rejoice/celebrate } \\
\hline No & 33 & 20.8 \\
\hline Yes & 125 & 78.6 \\
\hline \multicolumn{3}{|l|}{ Depression/fear control } \\
\hline No & 129 & 81.1 \\
\hline Yes & 30 & 18.9 \\
\hline \multicolumn{3}{|l|}{ Need to eat control } \\
\hline No & 148 & 93.1 \\
\hline Yes & 11 & 6.9 \\
\hline \multicolumn{3}{|l|}{ Public speaking } \\
\hline No & 158 & 99.4 \\
\hline Yes & 1 & 0.6 \\
\hline \multicolumn{3}{|l|}{ Studying } \\
\hline No & 153 & 96.2 \\
\hline Yes & 6 & 3.8 \\
\hline \multicolumn{3}{|l|}{ Pain control } \\
\hline No & 151 & 95.0 \\
\hline Yes & 8 & 5.0 \\
\hline \multicolumn{3}{|l|}{ Sleeping } \\
\hline No & 152 & 95.6 \\
\hline Yes & 7 & 4.4 \\
\hline \multicolumn{3}{|l|}{ Others } \\
\hline No & 99 & 62.3 \\
\hline Yes & 60 & 38.7 \\
\hline
\end{tabular}


Frequency of drug use over the last days

$\begin{array}{lcc}\text { None } & 14 & 8.8 \\ \text { Once a week } & 89 & 56.0 \\ \text { Twice a week or more } & 39 & 24.5 \\ \text { Almost every day } & 13 & 8.2 \\ \text { Daily } & 4 & 2.5 \\ \text { ne from class due to alcohol and drug use } & & 73.6 \\ \text { No } & 117 & 26.4 \\ \text { Yes } & 42 & 87.4 \\ \text { Nsion diagnosis } & & 12.6 \\ \text { No } & 139 & 81.1 \\ \text { Yes } & 20 & 18.9\end{array}$

Table 3- Bivariate analysis of factors associated with the use of alcoholic beverage and cannabis by Dentistry students of Faculdade Meridional (IMED), 2015.

\begin{tabular}{|c|c|c|c|c|c|c|c|c|c|c|}
\hline \multirow[t]{3}{*}{ Independent Variables } & \multicolumn{5}{|c|}{ Use of alcoholic beverage } & \multicolumn{5}{|c|}{ Use of cannabis } \\
\hline & \multicolumn{2}{|c|}{ No } & \multicolumn{2}{|c|}{ Yes } & \multirow[b]{2}{*}{$p$} & \multicolumn{2}{|c|}{ No } & \multicolumn{2}{|c|}{ Yes } & \multirow[b]{2}{*}{$p$} \\
\hline & $\mathrm{n}$ & $\%$ & $\mathrm{n}$ & $\%$ & & $\mathrm{n}$ & $\%$ & & $\%$ & \\
\hline Terms & & & & & 0.460 & & & & & 0.475 \\
\hline $\begin{array}{l}\text { I To IV (1 }{ }^{\text {st }} \text { and } 2 \text { ND } \\
\text { year) }\end{array}$ & 9 & 10.2 & 79 & 89.8 & & 61 & 69.3 & 27 & 30.7 & \\
\hline $\begin{array}{l}\text { V To VIII (3 } 3^{\text {rd }} \text { and } 4^{\text {th }} \\
\text { year })\end{array}$ & 6 & 8.5 & 65 & 91.5 & & 48 & 67.6 & 23 & 32.4 & \\
\hline Gender & & & & & 0.293 & & & & & $* 0.046$ \\
\hline Male & 2 & 5.6 & 34 & 94.4 & & 20 & 55.0 & 16 & 44.4 & \\
\hline Female & 13 & 10.6 & 110 & 89.4 & & 89 & 72.4 & 34 & 27.6 & \\
\hline Age group & & & & & 0.574 & & & & & 0.316 \\
\hline $16-25$ years & 14 & 9.7 & 130 & 90.3 & & 100 & 69.4 & 44 & 30.6 & \\
\hline 26 Years or older & 1 & 6.7 & 14 & 93.3 & & 9 & 60.0 & 6 & 40.0 & \\
\hline Marital Status & & & & & 0.600 & & & & & 0.164 \\
\hline Single & 14 & 9.3 & 136 & 90.7 & & 101 & 67.3 & 49 & 32.7 & \\
\hline Married/Stable Union & 1 & 11.1 & 8 & 88.9 & & 8 & 88.9 & 1 & 1.1 & \\
\hline RESIDENTS & & & & & 0.503 & & & & & 0.079 \\
\hline Alone/friends & 4 & 10.5 & 34 & 89.5 & & 22 & 57.9 & 16 & 42.1 & \\
\hline Family members & 11 & 9.1 & 110 & 90.9 & & 87 & 71.9 & 34 & 28.1 & \\
\hline Work & & & & & 0.076 & & & & & 0.317 \\
\hline No & 13 & 8.6 & 139 & 91.4 & & 103 & 67.8 & 49 & 32.2 & \\
\hline Yes & 2 & 28.6 & 5 & 71.4 & & 6 & 85.7 & 1 & 14.3 & \\
\hline Use of drugs for depression & & & & & *0.049 & & & & & ${ }^{*} 0.004$ \\
\hline No & 15 & 11.6 & 114 & 88.4 & & 95 & 73.6 & 34 & 26.4 & \\
\hline Yes & 0 & 0.0 & 30 & 100. & & 14 & 46.7 & 16 & 53.3 & \\
\hline Life Satisfaction & & & & & 0.193 & & & & & 0.183 \\
\hline $\begin{array}{l}\text { 1(Very dissatisfied/ } \\
\text { dissatisfied) }\end{array}$ & 8 & 12.7 & 55 & 87.3 & & 47 & 74.6 & 16 & 25.4 & \\
\hline 2 to 7 (others) & 7 & 7.3 & 89 & 92.7 & & 62 & 64.6 & 34 & 31.4 & \\
\hline
\end{tabular}

${ }^{*} \mathbf{p}<0.05-$ Statistically significant difference. 


\section{DISCUSSION}

The use of licit and illicit drugs is a public health issue worldwide, which leads to the performance of related studies. University students are often introduced to some of these substances. Young individuals aged 15 to 24 years are the target audience of many consumption and leisure industries as they are considered potential consumers of $\operatorname{PAS}^{12,13}$.

In this study, we observed that most of the interviewed university students uses or has used some type of PAS, predominantly alcohol followed by cannabis; a big portion of these students feels the negative influence of this practice on their studies. Almost all respondents use PAS with the purpose of well-being, which matched the high rate of dissatisfaction with life hereby reported.

According to data obtained in studies performed in different states of Brazil and in other countries, alcohol is the most used drug ${ }^{13-15}$. This substance depresses the central nervous system and affects reasoning abilities, logical thinking, judgment, and causes changes in motor coordination and reflexes. At the same time, it promotes a feeling of relaxation and pleasure. However, the use of licit drugs usually precedes the use of other psychoactive substances, such as cannabis and cocaine ${ }^{16}$.

The reasons for psychoactive substance use are related to the development stage of young individuals. Behaviors and characteristics of adolescence such as curiosity, peer pressure, entertainment, or pleasure incite drug use ${ }^{17}$. The easy access to licit or illicit drugs makes easier its experimentation by young individuals. Factors that induce uneasiness, anxieties, and depression greatly contribute for students to try several narcotic substances, which vary according to the emotional and psychological profile of each individual ${ }^{18}$. The present study showed that the main purpose of students who use PAS is relaxation, celebration, and depression control. In a similar study with medical students of Faculdade de Salvador, BA, Brazil, the motivation for use was pleasure and no course-related stress $^{8}$. However, in a study performed with post-graduation students, work overload and easy access to drugs enabled their use ${ }^{10}$. The use of PAS has been increasing among university students, given that starting university is an unknown experience for many individuals, and therefore, they may acquire more than new knowledge, but also new habits and new ways of acting and relating with people. Hence, trying this new territory, living with new groups, and other factors may contribute to PAS use ${ }^{19}$.

According to the II Household Survey performed in Brazil on drug use, conducted by the Brazilian Center of Information on Psychotropic Drugs (Cebrid), the prevalence of cocaine use assessed in 108 cities of the country was $2.9 \%$ in comparison to crack $^{20}$ use of $1.5 \%$. No students reported the use of crack in the present study. As for cocaine, $1.9 \%$ of students maintained the use at some point in life.

In this study, PAS most used by dentistry students was alcohol, followed by cannabis, psychoactive drugs, tobacco, LSD, and cocaine. The results of other studies are unanimous when affirming that tobacco figures as the second most used PAS in any geographical location and in any age group ${ }^{12-14,21}$. However, the present study shows tobacco in fourth place among the PAS most used by students, and cannabis in second place. It is observed that cannabis is the first initiation drug chosen among illicit drugs, whereas its use begins from 12 to 16 years old ${ }^{22}$. In this context a study called Monitoring Future, which consists of a series of national surveys with data collected annually from North-American university students since 1980, demonstrated that in 2014 , for the first time the daily use of cannabis surpassed the use of tobacco, because increasingly because fewer young individuals and young adults consider the use of cannabis as dangerous ${ }^{19}$.

There was no distinction between licit and illicit drugs in our study. If that was the case, tobacco would be the second most used licit PAS and cannabis would be the first illicit PAS choice. Data from the household survey of 2001, which covered 107 Brazilian cities with over 200 thousand inhabitants, showed that cannabis was the favorite illicit drug among respondents ${ }^{23}$. In the present study, the rate of young individuals that reported having used cannabis was expressively higher than data from the household survey of 2001, and it was closer to countries with the highest rates of cannabis use, such as the Unites States and Spain ${ }^{23}$. This fact should not be analyzed separately, but rather associated with the social context, especially with family relations, which have an undeniable influence on individual formation. Moreover, peer pressure is also considered a relevant factor for initiation and maintenance of cannabis use $\mathrm{e}^{24}$.

We used a scale in an attempt to relate the life satisfaction of the individual. The Satisfaction With Life Scale (SWLS) aims to estimate from a global assessment, individual satisfaction with current life situation and a life standard established as desirable. The assessments on quality of life and its components represent a new health indicator and may consist of a new alternative for clinical outcome ${ }^{25}$. In the present study, regarding the variable of life satisfaction, dentistry students were overall dissatisfied with their current life situations in terms of the standard pursued for a desirable life. In this aspect, most students are dissatisfied or very dissatisfied. The scores obtained for life satisfaction in this study differ from data presented by another study performed in southern Brazil, where university students of public and private institutions reported higher rate of satisfaction with their life situations when compared to dissatisfied students ${ }^{26}$.

For almost $80 \%$ of the students who participated in the research, alcohol or other drugs have an influence on intellectual development. More than one quarter of the respondents also reported that the use of these substances was responsible for the absence in academic activities at some point. This was also shown in the study performed with university students of a nursing school, where after drinking, $21 \%$ of students admitted missing class, $16.5 \%$ had driven, and $2.3 \%$ had suffered accidents or missed work $^{12}$. Some authors affirm, based on researches, that the chronic use of cannabis may cause learning, attention, and memory deficits, decreasing motivation, visual ability, and motor coordination, as well as anxiety and depression ${ }^{27}$. 
Programs supporting the full health of adolescents, such as the Life Skills Education by the World Health Organization $^{28}$, promotes the intellectual development of young individuals, encouraging them to face complex situations or daily issues.

The present study showed a relation between the independent variable "use of drugs for depression" and use of alcohol and cannabis. Studies showed that cannabis use increases the probability to develop a psychotic disease $^{29}$ and their use in adolescence has been associated with higher risk $^{30}$. The association between depression and cannabis use is long known there is a higher risk for the male gender; this observation is also shown in this study. Besides depression, other psychotic diseases such as anxiety, bipolar disorder, and schizophrenia show association with cannabis use $^{31}$. Along with this, a study suggests that individuals with higher genetic

\section{CONCLUSION}

The prevalence of PAS use is high among the Dentistry students interviewed. The PAS most used by students was alcohol, followed by cannabis, psychoactive drugs, and tobacco. Evidences indicate that some variables influence the use psychoactive substances by students. Regarding the life satisfaction aspect, most respondents reported dissatisfaction with their current life conditions.

Data hereby presented suggest the need for interventions in the academic environment, mainly in the institution studied, regarding PAS use. The design and predisposition for schizophrenia are as much more likely to use cannabis as and in more quantity than those with no genetic predisposition. Thus, besides epidemiological data showing these relations, clinical studies also confirm this findings ${ }^{32}$.

Data hereby presented were collected through a self-administered anonymous questionnaire, collectively filled in the classroom. Hence, the fact that questions were represented by self-reports may have led to memory bias and underreporting. Although the present research included a small number of university students from a specific course it intends to add relevant aspects for understanding social issues about the practice of PAS use, especially for illicit drugs. This may contribute to assessing the need for application of a multi-professional care service to PAS users within universities.

\section{REFERENCES}

1. World Health Organization (WHO). Global status report on alcohol and health. Switzerland: World Health Organization; 2014.

2. Rehm J, Room R, Monteiro M, Gmel G, Graham K, Rehn N, et al. Alcohol as a risk factor for global burden of disease. Eur Addict Res. 2003;9(4):157-64. DOI: http://dx.doi.org/10.1159/000072222

3. United Nations Office on Drugs and Crime (UNODC). World drug report. New Work: UNODC; 2014.

4. Peto R, Lopez AD, Boreham J, Thun M, Heath C Jr. Mortality from tobacco in developed countries: indirect estimation from national vital statistics. Lancet. 1992;339(8804):1268-78.

5. Colodel EV, Silva ELFM, Zielak JC, Zaitter W, Michel-Crosato E, Pizzatto E. Alterações bucais presentes em dependentes químicos. RSBO. 2009;6(1):44-8.

6. Gebreslassie G, Feleke A, Melese T. Psychoactive substances use and associated factors among Axum university students, Axum Town, North Ethiopia. BMC Public Health. 2013;13:693. DOI: http://dx.doi.org/10.1186/1471-2458-13-693

7. Portugal FB, Souza RS, Buaiz V, Siqueira MM. Use of drugs by Pharmacy students at the Federal University in Espírito Santo. J Bras Psiquiatr. 2008;57(2):127-32. DOI: http://dx.doi.org/10.1590/S0047-20852008000200008

8. Ribeiro EDP, Oliveira JA, Zambolin AP, Lauris JRP, Tomita NE. Abordagem integrada da saúde bucal de droga-dependentes em processo de recuperação. Pesqui Odontol Bras. 2002;16(3):239-45. DOI: http://dx.doi.org/10.1590/S1517-74912002000300010

9. WHO Assist Working Group. The alcohol, smoking and substance involvement screening test (ASSIST): development, reliability and feasibility. Addiction. 2002;97(9):1183-94.

DOI: http://dx.doi.org/10.1046/j.1360-0443.2002.00185.x

10. Rocha PR, David HMSL, Gomes AMT, Ronzani TM, Ronzani TM. Questionário sobre o consumo de álcool e drogas entre profissionais de saúde: um estudo exploratório. Tese (Mestrado) - Universidade do Estado do Rio de Janeiro. Rio de Janeiro: 2010.

11. Diener E, Emmons RA, Larsen RJ, Griffin S. The Satisfaction with Life Scale. J Pers Assess. 
1985;49(1):71-5. DOI: http://dx.doi.org/10.1207/s15327752jpa4901_13

12. Picolotto E, Libardoni LFC, Migott AMB, Geib LTC. Prevalência e fatores associados com o consumo de substâncias psicoativas por acadêmicos de enfermagem da Universidade de Passo Fundo. Ciênc Saúde Coletiva. 2010;15(3):645-54. DOI: http://dx.doi.org/10.1590/S1413-81232010000300006

13. Petroianu A, Reis DCF, Cunha BDS, Souza DM. Prevalência do consumo de álcool, tabaco e entorpecentes por estudantes de medicina da Universidade Federal de Minas Gerais. Rev Assoc Med Bras. 2010;56(5):568-71. DOI: http://dx.doi.org/10.1590/S0104-42302010000500019

14. Teixeira RF, Souza RS, Buaiz V, Siqueira MM. Psychoactive substance use among Espírito Santo Federal University odontology students. Ciênc Saúde Coletiva. 2010;15(3):655-62. DOI: http://dx.doi.org/10.1590/S1413-81232010000300007

15. Kassa A, Taddesse F, Yilma A. Prevalence and factors determining psychoactive substance (PAS) use among Hawassa University (HU) undergraduate students, Hawassa Ethiopia. BMC Public Health. 2014;14:1044. DOI: http://dx.doi.org/10.1186/1471-2458-14-1044

16. Santos CSM, Ganem KMG. A bebida alcoólica como "Porta de entrada" para o uso de outras drogas psicoativas. Rev Saúde Pesqui. 2013;6(2):305-13.

17. Monteiro CFS, Araújo TME, Sousa CMM, Martins MCC, Silva LLL. Adolescentes e o uso de drogas ilícitas: Um estudo. Rev Enferm UERJ. 2012;20(3):344-8.

18. Lemos KM, Neves NMBC, Kuwano AY, Tedesqui G, Bitencourt GV, Neves FBCS, et al. Uso de substâncias psicoativas entre estudantes de Medicina de Salvador (BA) Rev Psiquiatr Clín. 2007;34(3):118-24. DOI: http://dx.doi.org/10.1590/S0101-60832007000300003

19. Johnston LD, O'Malley PM, Miech RA, Bachman JG, Schulenberg JE. Monitoring the Future National survey results on drug use: 1975-2014. Overview, key findings on adolescent drug use. Ann Arbor: Institute for Social Research. Michigan: Institute for Social Research; 2015.

20. Santos MP, Rocha MR, Araujo RB. O uso da técnica cognitiva substituição por imagem positiva no manejo do craving em dependentes de crack. J Bras Psiquiatr. 2014;63(2):121-6. DOI: http://dx.doi.org/10.1590/0047-2085000000015

21. Miozzo L, Dalberto ER, Silveira DX, Terra MB. Consumo de substâncias psicoativas em uma amostra de adolescentes e sua relação com o comportamento sexual. J Bras Psiquiatr. 2013;62(2):93-100. DOI: http://dx.doi.org/10.1590/S0047-20852013000200001

22. Sanchez ZVDM, Nappo SA. Seqüência de drogas consumidas por usuários de crack e fatores interferentes. Rev Saúde Pública. 2002;36(4):420-30. DOI: http://dx.doi.org/10.1590/S0034-89102002000400007

23. Carlini EA, Galduróz JCF, Noto AR, Nappo SA. I Levantamento domiciliar sobre o uso de drogas psicotrópicas no Brasil: estudo envolvendo as 107 maiores cidades do país: 2001. Centro Brasileiro de Informações Sobre Drogas Psicotrópicas/ Universidade Federal de São Paulo. São Paulo: 2002.

24. Becker H. Los extraños: Sociologia de la desviación. Buenos Aires: Tiempo Contemporáneo; 1971.

25. Gonçalves DM, Kapczinski F. Transtorno mental, indicadores demográficos e satisfação com a vida. Rev Saúde Pública. 2008;42(6):1060-6. DOI: http://dx.doi.org/10.1590/S0034-89102008005000061

26. Bardagi MP, Hutz CS. Satisfação de vida, comprometimento com a carreira e exploração vocacional em estudantes universitários. Arq Bras Psicol. 2010;62(1):159-70.

27. Rigoni M, Oliveira M, Andretta I. Consequências neuropsicológicas do uso da maconha em adolescentes e adultos jovens. Ciênc Cogn. 2006;8:118-26.

28. World Health Organization (WHO). Life skills education in schools. Geneva: World Health Organization; 1997.

29. McGrath J, Welham J, Scott J, Varghese D, Degenhardt L, Hayatbakhsh MR, et al. Association between cannabis use and psychosis-related outcomes using sibling pair analysis in a cohort of young adults. Arch Gen Psychiatry. 2010;67(5):440-7. DOI: http://dx.doi.org/10.1001/archgenpsychiatry.2010.6

30. Arseneault L, Cannon M, Poulton R, Murray R, Caspi A, Moffitt TE. Cannabis use in adolescence and risk for adult psychosis: longitudinal prospective study. BMJ. 2002;325(7374):1212-3. DOI: https://doi.org/10.1136/bmj.325.7374.1212

31. Sanches RF, Marques JMA. Cannabis e humor. Rev Bras Psiquiatr. 2010;32(2):173-80. DOI: http://dx.doi.org/10.1590/S1516-44462010000200014

32. Power RA, Verweij KJ, Zuhair M, Montgomery GW, Henders AK, Heath AC, et al. Genetic predisposition to schizophrenia associated with increased use of cannabis. Mol Psychiatry. 2014;19(11):1201-4. DOI: http://dx.doi.org/10.1038/mp.2014.51 


\section{Resumo}

Introdução: O uso de substâncias psicoativas (SPA) é uma prática utilizada pelo homem desde seus primórdios. Entretanto, a partir dos anos 60 , teve seu consumo substancialmente aumentado, e se tornou conhecida por comprometer a saúde e ocasionar a morte de milhões de pessoas todos os anos.

Objetivo: O uso de substâncias psicoativas é uma prática utilizada há muitos anos, porém, a partir dos anos 60 , teve seu consumo substancialmente aumentado. O objetivo deste estudo foi verificar a prevalência do uso de substâncias psicoativas entre estudantes de Odontologia, bem como analisar a influência das variáveis sociodemográficas e identificar o nível de satisfação com a vida entre os estudantes.

Método: O delineamento é do tipo transversal composto por 159 estudantes de Odontologia de uma instituição de ensino de um município do sul do Brasil matriculados nos oito períodos do curso. Os sujeitos forma submetidos anonimamente a um questionário autoaplicável com perguntas referentes a variáveis sociodemográficas, uso de substâncias psicoativas (SPA) adaptadas pelo instrumento validado Teste de Triagem para Álcool, Tabaco e Substâncias (ASSIST), e a avaliação do grau de satisfação com a vida, a partir da Escala de Satisfação com a Vida (ESVC).

Resultados: O uso de SPA em algum momento da vida teve prevalência de 90,6\%, sendo, o álcool, a droga mais consumida, seguida pela maconha. O uso de medicamentos para depressão mostrou associação ao consumo de álcool. O consumo de maconha também esteve associado ao uso de antidepressivos, sendo a maconha mais consumida pelos homens. A maior parte da amostra relatou insatisfação com sua vida.

Conclusão: A prevalência do uso PAS é alta entre os estudantes de Odontologia entrevistados. O PAS mais utilizado pelos alunos foi o álcool, seguido de maconha, drogas psicoativas, e tabaco.

Palavras-chave: drogas ilícitas,usuários de drogas, entorpecentes, estudantes de odontologia

๑ The authors (2017), this article is distributed under the terms of the Creative Commons Attribution 4.0 International License (http://creativecommons.org/licenses/by/4.0/), which permits unrestricted use, distribution, and reproduction in any medium, provided you give appropriate credit to the original author(s) and the source, provide a link to the Creative Commons license, and indicate if changes were made. The Creative Commons Public Domain Dedication waiver (http://creativecommons.org/ publicdomain/zero/1.0/) applies to the data made available in this article, unless otherwise stated. 